\title{
Surgical cystotomy for refractory diabetic cystoid macular edema
}

This article was published in the following Dove Press journal:

Clinical Ophthalmology

\section{Koushik Tripathy}

Department of Vitreoretina and Uvea, ICARE Eye Hospital \& Postgraduate Institute, Noida, India
Correspondence: Koushik Tripathy Department of Vitreoretina and Uvea ICARE Eye Hospital \& Postgraduate Institute, E3A, Sector-26, Noida 20I30I, Uttar Pradesh, India

Tel +9l I20 2477600

Email drkoushiktripathy@

icarehospital.org

\section{Dear editor}

I read with interest the article on cystotomy for refractory diabetic cystoid macular edema (CME) by Asahina et al. ${ }^{1}$ Intraoperative optical coherence tomography (OCT) (RESCAN 700; Carl Zeiss Meditec AG, Jena, Germany) is a new interesting addition to ophthalmic surgeons' armamentarium. ${ }^{2}$ Few aspects regarding the manuscript ${ }^{1}$ need further discussion. 1) The exact definition of "refractory CME" needs elaboration. 2) The positive effect on visual recovery after surgery may also have been influenced by the simultaneous cataract surgery in some cases. It would be interesting to compare the visual gain of patients with cystotomy only versus cystotomy with cataract surgery. 3) A 41-gauge subretinal injection needle (DORC International, Zuidland, the Netherlands) $)^{3}$ may also be used for cystotomy. It has the theoretical potential of reduced surgical trauma compared to a 27 -gauge needle, and may also be used to flush the intraretinal fluid in such cases. 4) The exact role of intraoperative OCT will be more substantiated if the authors could provide a surgical video or figures showing the use of intraoperative OCT. 5) Puncture of the cystoid spaces at the macula is an innovative surgical technique. ${ }^{1,4}$ However, in the 1999 paper by Tachi et al, ${ }^{4}$ the visual acuity remained same or worsened after surgery in 17 of 22 eyes. CME puncture for long-standing refractory $\mathrm{CME}$ resulted in resolution of CME without a significant improvement in visual acuity in the study by Singh et al. ${ }^{5}$ In the study by Asahina et al, ${ }^{1} 18$ of 20 eyes had maintained or improved visual acuity after surgery. Thus, cystotomy adds to the limited treatment options for resistant diabetic CME.

\section{Disclosure}

The author reports no conflicts of interest in this communication.

\section{References}

1. Asahina Y, Tachi N, Asahina Y, Yoshimura K, Ueta Y, Hashimoto Y. Six-month postoperative outcomes of intraoperative OCT-guided surgical cystotomy for refractory cystoid macular edema in diabetic eyes. Clin Ophthalmol. 2017;11:2099-2105.

2. Tripathy K, Chawla R, Kumawat B, Sharma YR. Intraoperative optical coherence tomography imaging and assessment of the macula during cataract surgery: a novel technique. Ophthalmic Surg Lasers Imaging Retina. 2016;47(9):846-847.

3. Venkatesh P, Temkar S, Tripathy K, Chawla R. Intralesional antibiotic injection using $41 \mathrm{G}$ needle for the management of subretinal abscess in endogenous endophthalmitis. Int J Retina Vitreous. 2016;2:17.

4. Tachi N, Hashimoto Y, Ogino N. Cystotomy for diabetic cystoid macular edema. Doc Ophthalmol. 1999;97(3-4):459-463.

5. Singh RP, Margolis R, Kaiser PK. Cystoid puncture for chronic cystoid macular oedema. Br J Ophthalmol. 2007;91(8):1062-1064. 
Dove Medical Press encourages responsible, free and frank academic debate. The content of the Clinical Ophthalmology 'letters to the editor' section does not necessarily represent the views of Dove Medical Press, its officers, agents, employees, related entities or the Clinical Ophthalmology editors. While all reasonable steps have been taken to confirm the content of each letter Dove Medical Press accepts no liability in respect of the content of any letter, nor is it responsible for the content and accuracy of any letter to the editor.

Clinical Ophthalmology

\section{Publish your work in this journal}

Clinical Ophthalmology is an international, peer-reviewed journal covering all subspecialties within ophthalmology. Key topics include: Optometry; Visual science; Pharmacology and drug therapy in eye diseases; Basic Sciences; Primary and Secondary eye care; Patient Safety and Quality of Care Improvements. This journal is indexed on

\section{Dovepress}

PubMed Central and CAS, and is the official journal of The Society of Clinical Ophthalmology (SCO). The manuscript management system is completely online and includes a very quick and fair peer-review system, which is all easy to use. Visit http://www.dovepress.com/ testimonials.php to read real quotes from published authors. 